American Journal of Animal and Veterinary Sciences 7 (2): 96-103, 2012

ISSN 1557-4555

(C) 2012 Science Publications

\title{
Studies on the Seasonal Changes in Antioxidant Enzymes Activity on Differently, Polluted Areas along the Bay of Bengal Employing Perna viridis as an Animal Model
}

\author{
C. Amutha and P. Subramanian \\ Department of Animal Science, Bharathidasan University, \\ Tiruchirappalli-620024, Tamilnadu, India
}

\begin{abstract}
Antioxidants are the innate or acquired molecules capable of slowing down or preventing the oxidative damage (damage due to reactive oxygen species) that caused by free radicals. The antioxidant enzyme activity in response to season as well as hydrocarbon pollution was attempted. Rayapuram fishing harbor of Chennai (Station-1) is highly oil contaminated with oil sleeks on the surface. The relatively moderate oil contaminated area (Station-2) is about $2 \mathrm{~km}$ away from the fishing harbor and the least contaminated Vellar estuary Parangipettai (Station-3) was considered as the reference site. The 2 year (2005-2007) observation was recorded seasonally; the antioxidant activity varied seasonally and organally (digestive gland, gill and mantle) in the marine green mussel Perna viridis. The common antioxidant enzymes such as Catalase (CAT), Superoxide Dismutase (SOD) and Glutathione Reductase (GR) activity were evaluated. The CAT and SOD are responded well with seasons (i.e., monsoon, pre-monsoon, post-monsoon and summer seasons). During monsoon period, both CAT and SOD activity are very low in all the Stations, in both pre-monsoon and post-monsoon period their activity were moderate and higher enzyme activity was noted during summer season. On contrary, the GR activity was noted as very low during summer and very high during pre or post monsoon and the activity was moderate during monsoon period. In addition the GR activity respond to temperature also but the other antioxidants CAT and SOD yielded no detectable activity. Among the organs liver showed higher CAT and SOD activity when compared to gill and mantle but the GR exhibited the increased activity in gill but not in liver.
\end{abstract}

Key words: Perna viridis, antioxidants, CAT, SOD, GR, free radicals, bay of bengal

\section{INTRODUCTION}

Generally, Free-radicals are highly reactive chemicals that attack molecules by capturing electrons and thus modifying the chemical structures and also make it unstable. Valko et al. (2007) stated under normal physiological condition, animals maintained a balance between generation and neutralization of Reactive Oxygen Species (ROS). However when organisms are subjected to xenobiotic compounds, rate of production of ROS in cells get increased along with hydrogen peroxide $\left(\mathrm{H}_{2} \mathrm{O}_{2}\right)$, Hypochlorous acid $(\mathrm{HClO})$ and free radicals including hydroxyl radical $(\mathrm{OH})$ and superoxide anion $\left(\mathrm{O}_{2}{ }^{\bullet}-\right)$. They are normally neutralized in the body employing the following enzymes.

Catalase are enzymes that catalyse the conversion of hydrogen peroxide to water and oxygen, using either an iron or manganese cofactor (Zamocky and Koller,
1999; Chelikani et al., 2004). Superoxide Dismutase (SOD) are a class of closely related enzymes that catalyse the breakdown of the superoxide anion into oxygen and hydrogen peroxide (Johnson and Giulivi, 2005; Nozik-Grayck et al., 2005). SOD enzymes are present in almost all aerobic cells and in extracellular fluids. Glutathione reductase is an enzyme which reduces glutathione disulphide (GSSG) to the sulfhydryl form GSH, which is an important cellular antioxidant (Meister and Anderson, 1983; Mannervik, 1987). For every mole of GSSG one mole of NADPH is required for reduction reaction. Where as in the cells exposed to high levels of oxidative stress (e.g., red blood cells) need up to $10 \%$ of the available glucose for the production of the NADPH, in this reaction (Mannervik, 1987). The non enzymatic compounds like beta-carotene, lycopene, vitamins $\mathrm{C}, \mathrm{E}$ and $\mathrm{A}$ and some other substances also exerts antioxidant properties.

Corresponding Author: P. Subramanian, Department of Animal Science, Bharathidasan University, Tiruchirappalli-620024, Tamilnadu, India 
Mechanism: All organisms respire to survive, thus have their own cellular antioxidative defense system, involving both enzymatic as well as non-enzymatic components. Enzymatic pathway consists of SOD, CAT, GSH, GPX. SOD dismutate the $\mathrm{O}_{2}{ }^{\bullet}-$ in to $\mathrm{H}_{2} \mathrm{O}_{2}$ which is reduced to water and molecular oxygen by CAT or is neutralized by GPX, that catalyzes the reduction of $\mathrm{H}_{2} \mathrm{O}_{2}$ to water and organic peroxide to alcohols using GSH as a source of reducing equivalent. Gulutathione Reductase (GSH) regenerated from oxidized glutathione (GSSG), which is a scavenger for ROS as well as a substrate of the other enzymes. GST conjugates xenobiotics with GSH for its excretion (Livingstone et al., 1992; Arun and Subramanian, 1998; Halliwell and Gutteridge, 2007).

\section{MATERIALS AND METHODS}

During the study period (2005-2007), samples of water and biota were collected fortnightly, the data were pooled seasonally to understand the seasonal effect. The four distinct seasons were monsoon (October to December) post-monsoon (January to March), summer (April to June) and pre-monsoon (July to September) periods. Site Selection Sampling sites surveyed along the Southeast coast of India represented different oil contamination scenarios. Two sites were located in the Tamilnadu state capital city Chennai; (Station-1, Kasimedu fishing harbor, Rayapuram, at Chennai is heavily oil polluted and Station-2, about 3 $\mathrm{km}$ off-shore from the harbor, is moderately oilpolluted).The least oil polluted site is Station-3, Vellar estuary, Paragipettai, Cuddalore District, which also supports a fishing harbor and was selected as the reference site (Fig. 1).

Animal Selection and Collection: The experimental animals, the green mussel Perna viridis were collected fortnightly between January 2005 and December 2007, from each Station. Immediately after collection, mussels' length (mean $10.086 \pm 0.77 \mathrm{~cm}$ ) and weight (mean $104 \pm 20.38 \mathrm{~g}$ ) were measured. At least three animals were sacrificed for organ collection. Liver (hepatopancreas), gill (ctenidium) and foot (muscle) were dissected out, stored in Cryocane (liquid nitrogen), taken to the laboratory and analyzed within $24 \mathrm{~h}$. The in situ environmental parameters such as $\mathrm{pH}$, temperature and salinity were measured using Water Analysis kit (Century Instruments Pvt. Ltd. India) and Refractometer (ERMA INC. Tokyo, Japan). Oil and grease level was quantified by Solid-Phase, PartitionGravimetric Method (ASTM, 2003). Along the Rayapuram beach in Station-1 (Kasimedu fishing harbor) mussels were attached as clusters on the piers and concrete pillars. At Station-2 (off-shore area) they were attached on anchored craft, wrecked and sunken crafts, rocks and ropes and were collected by employing local diving fishermen with a boat. At Station-3 (Vellar estuary) mussels were found attached to pillars of a railway bridge and piers of the jetty. The maximum of $1500 \mathrm{mg}$ each of liver, gill and foot tissues were homogenized in two volumes of $0.1 \mathrm{M}$ sodium phosphate buffer containing $2 \mathrm{mM}$ glutathione and 1 $\mathrm{mM}$ Ethylene-Diamine-Tetra Acetic acid (EDTA) tetrasodium salt, $\mathrm{pH}$ 6.5, using Polytron homogenizer (Mini Polytron, Switzerland). The homogenates were centrifuged at $12500 \mathrm{~g}$ for $20 \mathrm{~min}$ to remove cell debris and mitochondria. The supernatants were centrifuged for $75 \mathrm{~min}$ at $135000 \mathrm{~g}$ to sediment the microsomes. The microsomal pellets were resuspended with two volumes of $0.1 \mathrm{M}$ phosphate buffer ( $\mathrm{pH} 8.0$ ) containing $0.15 \mathrm{M}$ potassium chloride and $20 \%$ glycerol, then stored in liquid nitrogen container until analysis. Generally, Antioxidant enzymes activity was measured in freshly prepared samples, but for the determination of the Michaelis and Menten constant $(\mathrm{km})$ and the Q10 value, frozen samples were used. The cellular fraction protein concentration was determined by the method of Bradford (1976), which ranged between 4 and $10 \mathrm{mg} \oplus$ $\mathrm{mL} 1$. All operations were performed at $4^{\circ} \mathrm{C}$.

\section{Antioxidant enzymes:}

Catalase: The reaction mixture contained $50 \mathrm{mM}$

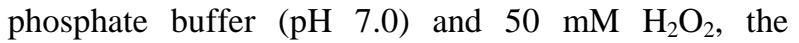
reaction rate was measured at $240 \mathrm{~nm}$. The extinction coefficient of $\mathrm{H}_{2} \mathrm{O}_{2}$ was $40.0 \mathrm{M}^{-1} \mathrm{~cm}^{-1}$. One unit of Catalase was defined as $1 \mu \mathrm{mol}$ of $\mathrm{H}_{2} \mathrm{O}_{2}$ degraded $\min ^{-1}$ $\mathrm{mg}^{-1}$ protein

Superoxide Dismutase (SOD) assay: Add $200 \mu \mathrm{L}$ of 0.1 M Ethylene Diamine Tetra Acetic (EDTA)/Cyanide mixture to $100 \mu \mathrm{L} \mathrm{NBT}$ and $10 \mu \mathrm{L}$ sample, Phosphate buffer was used to make up to $3 \mathrm{~mL}$ total reaction mixture, a series of samples ranging from 0.1-10 micrograms is recommended. A tube containing approximately $100 \mu \mathrm{g}$ will generally produce maximum inhibition. Place the tubes in a light box providing uniform light intensity. (A foil-lined box approximately 4' long X 8" X 6" with an internally mounted $40 \mathrm{~W}$ fluorescent bulb has been used successfully). Incubate the tubes for 5-8 min to achieve a standard temperature. At zero time and at time intervals add $0.05 \mathrm{~mL}$ riboflavin. Incubate all tubes in the light box for $12 \mathrm{~min}$ and at time intervals (at every $3 \mathrm{~min}$ ) read $\mathrm{A}_{560}$. Determine percent inhibition of NBT reduction. Plot percent inhibition versus amount of enzyme in test. Determine the amount of enzyme resulting in one half of maximum inhibition. No enzyme as reference. 


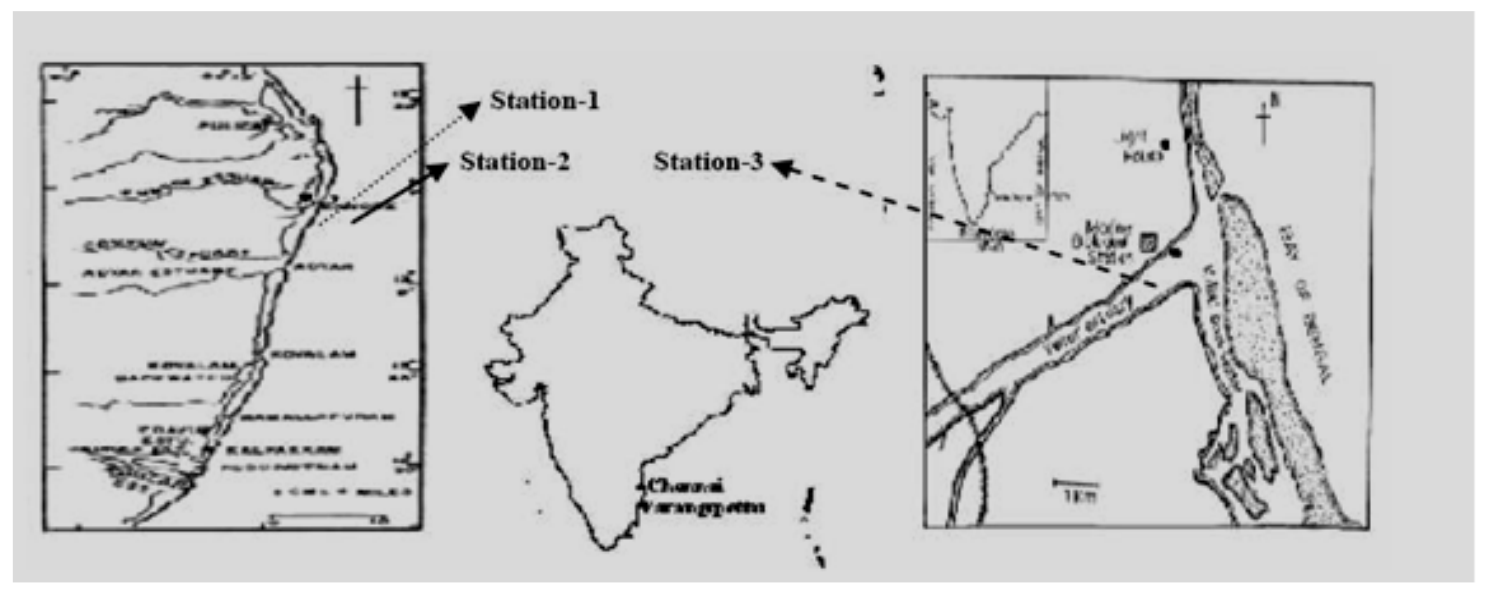

Fig. 1: Indication the sampling Station along the coramental coast of Tamulandu

Glutathione reductase (Carlberg and Mannervik, 1975): The reaction system of $1 \mathrm{~mL}$ contained: $1.0 \mathrm{mM}$ GSSG, $0.1 \mathrm{mM}$ NADPH, $0.5 \mathrm{mM}$ EDTA, $0.10 \mathrm{M}$ sodium phosphate buffer ( $\mathrm{pH}$ 7.6) and $100 \mu \mathrm{L}$ of sample to give change in absorbance $\mathrm{min}^{-1}$. The disappearance of NADPH was monitored for $5 \mathrm{~min}$ at $340 \mathrm{~nm}$. One unit will reduce $1.0 \mu \mathrm{mol}$ of oxidized glutathione $\mathrm{min}^{-1}$ at $\mathrm{pH}$ 7.6. Protein concentrations were determined according to Bradford (1976) using bovine serum albumin as the standard.

\section{RESULTS AND DISCUSSION}

Physicochemical parameters in different seasons: The physiochemical parameters such as salinity, temperature and $\mathrm{pH}$, besides the oil and grease from three different stations from January 2005 to December 2007 were pooled season ( monsoon, pre-monsoon, post monsoon and summer seasons) wise and given in Table 1. Almost all the evaluated environmental parameters exhibit a uniform seasonal trend in all the three stations studied. The Station-1 and 2 have little seasonal influx of water from inland water bodies and thus the salinity ranges from $30-34 \%$ o. Whereas the reference site Vellar estuary have periodic drain of water and the salinity fluctuate between 22-33\%o during monsoon to summer of the study period. The length and weight of the animals (Perna viridis) were measured periodically (in each collection) and their length (mean $10.086 \pm 0.77 \mathrm{~cm}$ ) and weight (mean $104 \pm 20.38 \mathrm{~g}$ ) were correlated and found a significant $(\mathrm{r}=0.785, \mathrm{P}<0.01)$ positive relationship.

Catalase activity in P.viridis during different seasons: During the study period (2005-2007) the liver, foot and gill of $P$. viridis from the study Stations were analyzed during different seasons such as summer (Apr.-June), pre-monsoon (July-Sep.), monsoon (Oct.Dec.) and post-monsoon (Jan-Mar) periods. Among the season wise analysis of liver fraction catalase activity was higher during summer season in all the Stations (1st Station, $114 \pm 15.25 \mu \mathrm{mol} \mathrm{mg}{ }^{-1}$ protein $\mathrm{min}^{-1}$, followed by 2 nd Station, $53.66 \pm 8.26 \mu \mathrm{mol} \mathrm{mg}^{-1}$ protein $\min ^{-1}$ and 3rd Station, 23 $\pm 2.58 \mu \mathrm{mol} \mathrm{mg}{ }^{-1}$ protein $\mathrm{min}^{-1}$ respectively). Where as the catalase activities were low during monsoon period [Station-1, $(65.13 \pm 10.59 \mu \mathrm{mol}$ $\mathrm{mg}^{-1}$ protein $\left.\mathrm{min}^{-1}\right)$, Station-2 $\left(33.76 \pm 6.42 \mu \mathrm{mol} \mathrm{mg}{ }^{-1}\right.$ protein $\left.\mathrm{min}^{-1}\right)$ and Station-3 $(11 \pm 2.42 \mu \mathrm{mol} \mathrm{mg}$ protein $\mathrm{min}^{-1}$ ) respectively]. The remaining seasons shows more or less equal catalase activity. The monsoonal minimum catalase activity ascends towards summer, then decline towards monsoon (Fig. 2-4). Among the different organs analyzed higher activity was evident in liver (Fig. 2) followed by foot (Fig. 3) and gill (Fig. 4). The seasonal pattern of enzyme activity was reflected in the organs (liver, foot and gill) analyzed also.

SOD activity in $P$. viridis during different seasons: The SOD activity showed a peak during summer and it descends to form a trough in monsoon and then ascends towards summer. The observed higher activity during summer were, Station-1 $\left(86.82 \pm 11.36\right.$ unit $\mathrm{mg}^{-1}$ protein $\mathrm{min}^{-1}$ ) followed by Station-2 $\left(36.43 \pm 5.25\right.$ unit $\mathrm{mg}^{-1}$ protein $\mathrm{min}^{-1}$ ) and then Station-3 (13.21 \pm 2.24 unit mg ${ }^{-1}$ protein $\left.\min ^{-1}\right)$. On the other side very less activity were noted during monsoon period in Station-1 (54.6 $\$ 12.78$ unit $\mathrm{mg}^{-1}$ protein $\left.\mathrm{min}^{-1}\right)$ followed by $(14.56 \pm 6.72$ unit $\mathrm{mg}^{-1}$ protein $\left.\mathrm{min}^{-1}\right)$ in Station- 2 and $\left(7 \pm 0.78\right.$ unit $\mathrm{mg}^{-1}$ protein $\mathrm{min}^{-1}$ ) in Station-3. Similarly the evaluated SOD activity in different organs also followed the trend of seasons. The higher enzyme activity was noted in liver $\left(86.82 \pm 11.36\right.$ unit mg ${ }^{-1}$ protein $\mathrm{min}^{-1}$ ) (Fig. 5) followed by gill $\left(54.23 \pm 7.12 \mathrm{unit} \mathrm{mg}^{-1}\right.$ protein $\mathrm{min}^{-1}$ ) (Fig. 6) and the least in the foot $\left(43.45 \pm 5.64 \mathrm{unit} \mathrm{mg}^{-1}\right.$ protein $\left.\mathrm{min}^{-1}\right)$ (Fig. 7) during summer seasons, where as in the monsoon seasons the lowest values were recorded. 
American J. Animal \& Vet. Sci., 7 (2): 96-103, 2012

Table 1: Physico-chemical characteristics of water bodies at different sampling station by season

\begin{tabular}{|c|c|c|c|c|}
\hline & $\mathrm{pH}$ & $\begin{array}{l}\text { Temperature } \\
\left({ }^{\circ} \mathrm{C}\right)\end{array}$ & $\begin{array}{l}\text { Salinity } \\
(\% \circ)\end{array}$ & $\begin{array}{l}\text { Oil and } \\
\text { grease } \\
\mathrm{mg} \mathrm{L}^{-1} \\
\text { (wet wt) }\end{array}$ \\
\hline \multicolumn{5}{|c|}{ Rayapuram harbor (Station-1) } \\
\hline Summer & $7.80 \pm 2.2$ & $28.0 \pm 3.0$ & $33 \pm 1.5$ & 308.0 \\
\hline Premonsoon & $7.50 \pm 1.5$ & $26.0 \pm 2.2$ & $31 \pm 1.2$ & 194.5 \\
\hline Monsoon & $7.30 \pm 1.2$ & $25.0 \pm 2.4$ & $29 \pm 1.2$ & 58.1 \\
\hline Post monsoon & $7.60 \pm 1.6$ & $28.0 \pm 2.5$ & $31 \pm 1.5$ & 192.1 \\
\hline \multicolumn{5}{|c|}{ Rayapuram off coast (Station-2) } \\
\hline Summer & $7.70 \pm 1.8$ & $27.5 \pm 3$ & $32 \pm 1.5$ & 151.0 \\
\hline Permosoon & $7.40 \pm 1.4$ & $26.0 \pm 2.2$ & $30 \pm 1.2$ & 98.4 \\
\hline Monsoon & $7.25 \pm 1.35$ & $25.0 \pm 2.4$ & $29 \pm 1.5$ & 37.8 \\
\hline Post monsoon & $7.50 \pm 1.2$ & $28 \pm 2.5$ & $31 \pm 1.0$ & 82.1 \\
\hline \multicolumn{5}{|c|}{ Parangipettai (Station-3) } \\
\hline Summer & $7.30 \pm 1.6$ & $29.0 \pm 4.1$ & $31 \pm 2.2$ & 42.4 \\
\hline Permosoon & $7.50 \pm 1.4$ & $26.0 \pm 2.0$ & $28 \pm 2.3$ & 20.2 \\
\hline Monsoon & $7.15 \pm 1.1$ & $24.0 \pm 1.7$ & $19 \pm 4.2$ & 8.4 \\
\hline Post monsoon & $7.40 \pm 1.3$ & $27.0 \pm 3.2$ & $26 \pm 3.1$ & 21.0 \\
\hline
\end{tabular}

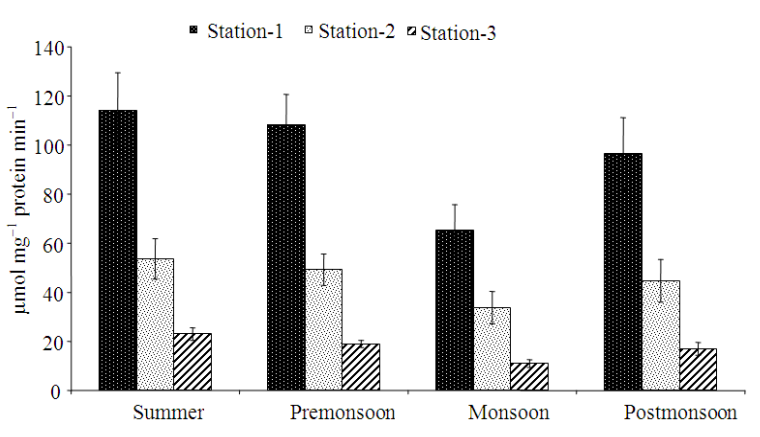

Fig. 2: Catalase activity of Perna viridis liver s9 fraction during different seasons

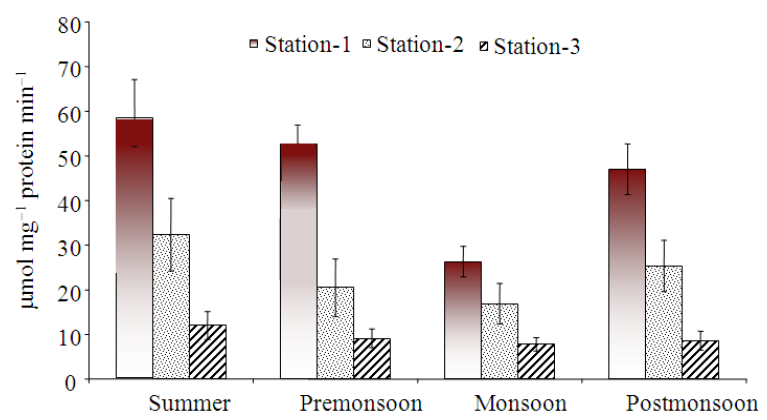

Fig. 3: Catalase activity on foot s9 fraction in Perna viridis during different seasons

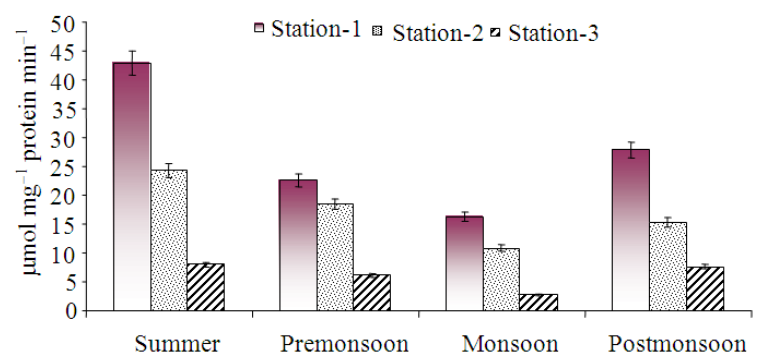

Fig. 4: Catalase activity on foot s9 fraction in Perna viridis during different seasons

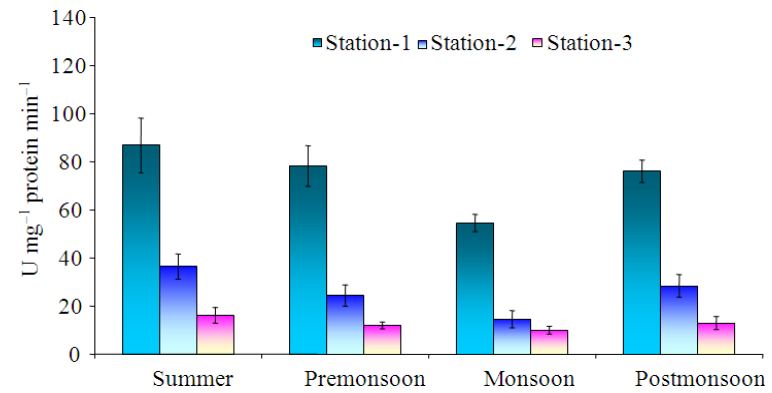

Fig. 5: SOD activity in Perna viridis liver s9 fraction during different seasons

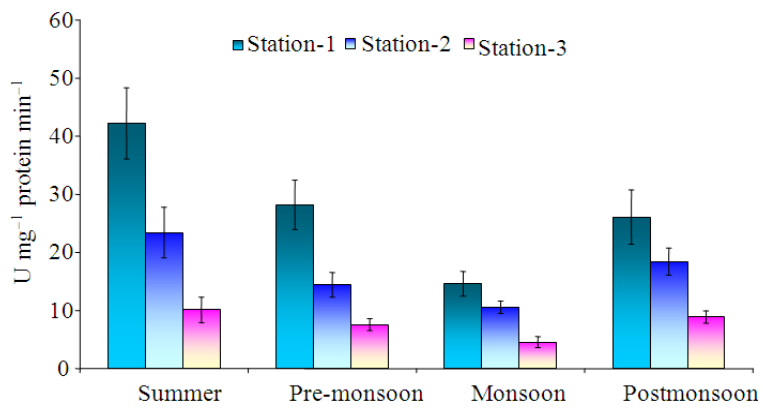

Fig. 6: SOD activity in Perna viridis foot s9 fraction during different seasons

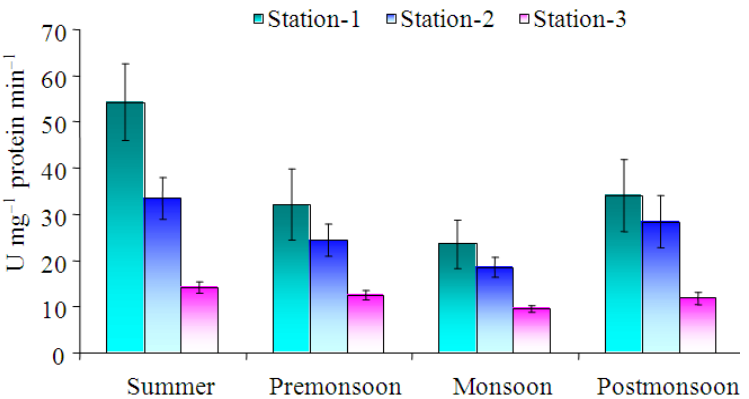

Fig. 7: SOD activity in Perna viridis gill s9 fraction during different seasons

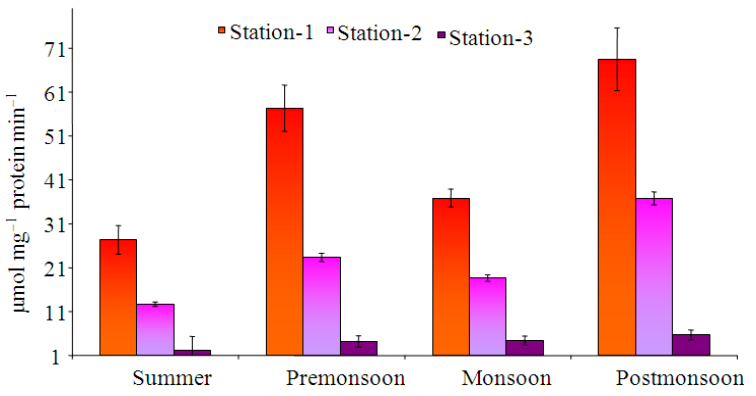

Fig. 8: Glutathione reductase activity in $P$. viridis hepatopancreas s9 fraction during different seasons 
Glutathione reductase (GSH): Gulathione reductase activity behaves differently from the other two (catalase and SOD) antioxidant enzyme. Here the minimum level of GSH activity was noted in liver fraction during both summer and monsoon seasons in all the three Stations when compared to other seasons (Fig. 8). The highest level was observed during both post and premonsoon seasons in liver. The GSH activity during post monsoon in Stations1,2 and 3 were $68.45 \pm 10.36 \mu \mathrm{mol} \mathrm{mg}^{-1}$ protein $\mathrm{min}^{-1}$, $36.78 \pm 6.22 \mu \mathrm{mol} \mathrm{mg}{ }^{-1}$ protein $\min ^{-1}$ and $5.67 \pm 1.21 \mu \mathrm{mol}$ $\mathrm{mg}^{-1}$ protein $\mathrm{min}^{-1}$ respectively. The minimum activity recorded during summer in Station-1 $(27.36 \pm 6.98 \mu \mathrm{mol}$ $\mathrm{mg}^{-1}$ protein $\left.\mathrm{min}^{-1}\right)$ followed by $(12.72 \pm 6.72 \mu \mathrm{mol} \mathrm{mg}$ protein $\left.\min ^{-1}\right)$ in Station-2 and in Station-3 (2.12 \pm 0.32 $\mu \mathrm{mol} \mathrm{mg}{ }^{-1}$ protein $\mathrm{min}^{-1}$ ).

Between the seasonal fluctuations, liver, foot and gill shown the elevated level of GSH in post monsoon subsequently declined in summer, then increased in premonsoon and falls in monsoon. Among all the Station and all the seasons studied, the Rayapuram fishing harbor (Station-1) evidenced higher GSH activity when compare to other Stations and very lesser activity in Parangipettai (Station-3).

\section{CONCLUSION}

The higher level of GSH enzyme activity was noted in foot fraction during post monsoon seasons at all Stations [Station-1 $\left(39.86 \pm 8.12 \mu \mathrm{mol} \mathrm{mg}{ }^{-1}\right.$ protein $\left.\min ^{-1}\right)$ Station-2 $\left(26.78 \pm 4.23 \mu \mathrm{mol} \mathrm{mg}{ }^{-1}\right.$ protein $\left.\min ^{-1}\right)$ and Station-3 $\left(2.4 \pm 0.56 \mu \mathrm{mol} \mathrm{mg}^{-1}\right.$ protein $\left.\left.\mathrm{min}^{-1}\right)\right]$. The lowest level of GSH activity was encountered in gill fraction than the liver and foot (Fig. 9). The higher level of GSH activity was recorded during Post monsoon in gill (Fig. 10) in all the study sites [Station-1 $\left(24.14 \pm 3.24 \mu \mathrm{mol} \mathrm{mg}{ }^{-1}\right.$ protein $\left.\mathrm{min}^{-1}\right)$ followed by station-2 $\left(14.44 \pm 2.13 \mu \mathrm{mol} \mathrm{mg}{ }^{-1}\right.$ protein $\left.\mathrm{min}^{-1}\right)$ and station- $3\left(1.89 \pm 09 \mu \mathrm{mol} \mathrm{mg}{ }^{-1}\right.$ protein $\left.\min ^{-1}\right)$ ].

Physico-chemical parameters: The water quality parameters such as water temperature, salinity, $\mathrm{pH}$, oil and grease exhibited a uniform seasonal trend in all the stations studied, that reflects seasonal pattern of south east coast of India. Their highest level was observed during summer and the lowest level during monsoon. A similar seasonal trend of environmental parameters were reported by Subramanian (1992) from VellarColeroon estuarine complex. Presently observed higher level of oil and grease in station 1, was twofold higher than station- 2 and 7 fold higher than station-3 (Table, 1). It could be related to the higher oil pollution in this station due to the congregation of more fishing trawlers and the related activities like oil filling, washing, repairing. Further, the summer maximum and monsoonal minimum indicated the rain water flooding dilute, disburse and taken away of these floating pollutants, thus the lower values. Identical observation was recorded by Wetzel and Vleet (2004) with the support hydrocarbon data of mussel, further stated "Indigenous mussels were least impacted by petroleum contamination at open-water stations indicating that physical processes of tidal or wind or rain activities can remove organic contaminants such as petroleum from these areas more effectively", but more affected in partially-enclosed areas.

In the oxidative metabolism the role of antioxidants are very essential. The antioxidants are mainly divided into enzymatic and non enzymatic. Antioxidant requirements are mostly derived from the food sources. Present study give emphasis the enzymatic antioxidants and thus evaluated the same in Perna viridis under environmental and experimental stress conditions. Interactions between abiotic and biotic factors are more common in the aquatic environments. Among abiotic factors, saline and thermal stress leads physiological disorder in animals, which primarily affects the metabolism, resulting in the accumulation of ROS (Arun and Subramanian, 1998; Rajagopal et al., 2005). Thereby the season oriented three antioxidant enzyme activity was primarily observed in this study.

Catalase: The present study evidenced that the catalase activity was tissues specific and environmental parameter sensitive. The maximum catalase activity was recorded in the order of digestive glands (liver), foot and gill respectively. In the case of long (field during summer) term exposure to non-optimal salinity and temperatures affect the activity of scavenging enzyme catalase. Identical trend was demonstrated in the digestive gland, foot and gill tissues of zebra mussel (Khessiba et al., 2005; Parihar et al., 1997). The seasonal activity of catalase exhibit a summer hike and a monsoonal trough. It was coincide with the hydrocarbon pollutant level in that seasons (Bhat and Desai, 1998). It would reveal the ability of the animal to produce catalase was limited to its tolerance level then the production was contained in higher concentration of xenobiotics as well as longer duration (Sturve et al., 2005).

Superoxide Dismutase (SOD): SOD was designated as an index for a range of contaminants (Cossu et al., 2000). The SOD exerts an elevated level in liver than foot and gill. Similar finding was reported in another species of 
bivalves, Scapharca inaequivalvis and Tapes philippinarum (Lushchak and Bagnyukova, 2006; Santovito et al., 2005; Irato et al., 2001). Further, who stated the experience of some species-specific differences that could be attributed to their different adaptation and habitat. In that the recorded high SOD activities in the gills of both the species may be related to their physiological role in respiration (Irato et al., 2001). In the present study the SOD activity increased in liver during summer season and very minimum in monsoon period. It could be attributed to the higher hydrocarbon level in the summer and the minimum during monsoon due to washing off and higher dispersion/dilution in the season. The gill showed second place for the enzyme activity but foot exhibited very lower activity than other tissues. So liver is the ideal organ to evaluate the activity of SOD against the xenobiotics exposure. In the xenobiotics exposure profile SOD showed a positive correlation with catalase $(\mathrm{r}=0.888, \mathrm{p}<0.05)$. SOD activity in the gills of $H$. fossilis on short-term temperature showed similar enhancement (Nozik-Grayck et al., 2005; Valko et al., 2007). The same conditions of higher activity in Perna viridis also noted in long term exposure in this study. Though SOD activity in response to season and $\mathrm{PAH}$ was evident from this study but (Power and Sheehan, 1995) reported that SOD as an biomarker index for pesticide pollutants.

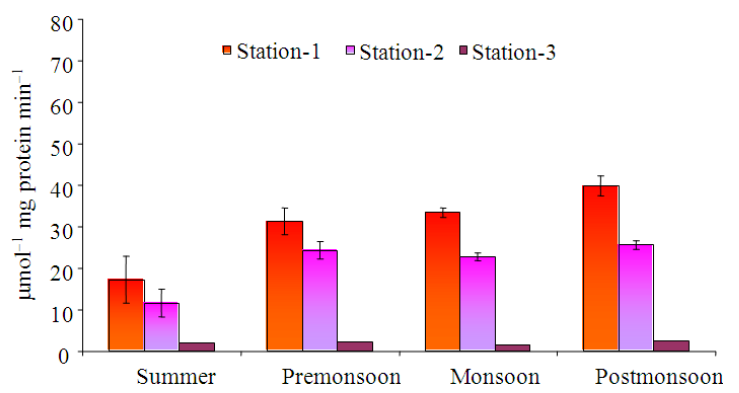

Fig. 9: Glutathione reductase activity in $P$. viridis foot s9 fraction during different seasons

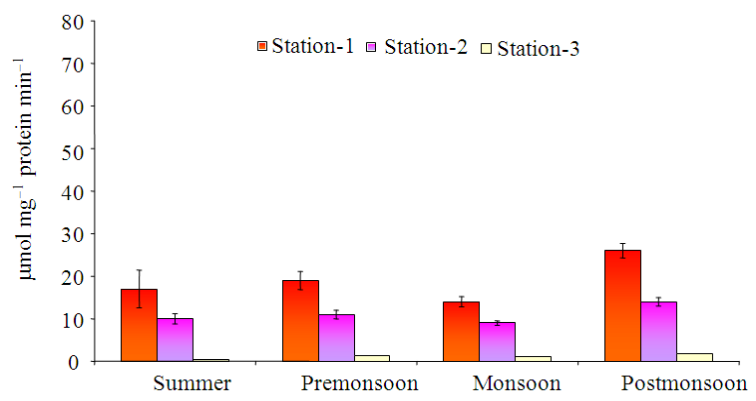

Fig. 10: Glutathione reductase activity in P.viridis gill $\mathrm{s} 9$ fraction during different seasons
Glutathione reductase (GSH): Among the three antioxidants studied GSH seems to be highly sensitive to environmental dynamic such as dissolved oxygen, salinity and temperatures, besides xenobiotics. The seasonal change in environmental parameters modulates the induction of antioxidant enzymes as a protective measure against stress including potential toxicity which increased the ROS formation (Santovito et al., 2005). This GSH enzyme catalyzes the reduced Nicotinamide Adenine Dinucleotide Phosphate (NADPH)-dependent reduction of the disulfide bond of oxidized glutathione. A major function of $\mathrm{GSH}$ is to serve as a reductant in the oxidation-reduction processes; a function resulting in the formation of glutathione disulfide (GSSG). Glutathione STransferases (GSTs) are ubiquitous multifunctional enzymes, which play a key role in cellular detoxification. The enzymes protect the cells against toxicants by conjugating them to glutathione, thereby neutralizing their electrophonic sites and rendering the products more water-soluble for elimination. The temperature stress activates increased level of total glutathione, initially which serves as a compensatory mechanism, to allow mussels to maintain constant GSH/GSSG ratio despite heat induced oxidative stress (Lushchak and Bagnyukova, 2006). In this study the seasonal and experimentally given temperatures exert stress to the GSH activity. Similar effect in the long term exposure to temperature was recorded by Zhang et al. (2003). Notably the GSH level increased positively in response to temperature in the laboratory exposure, surprisingly it decreased at longer time exposure in the field i.e., during summer.

The GSH and catalase imparted an identical trend during summer season $(\mathrm{r}=0.998, \mathrm{p}<0.01)$. The same condition was observed in the organs like liver, gill and foot of M.galloprovincialis and $H$. fossilis (Khessiba et al., 2005; Parihar et al., 1997), when exposed to heat. The liver showed higher enzyme activity during both the post and pre monsoon seasons. Identical season related higher enzyme elevation of GSH (both post and premonsoon) than other seasons were recorded (Meister and Anderson, 1983).

Among all the Station and all the seasons studied, the Rayapuram fishing harbor (Station-1) evidenced higher GSH activity when compare to other Stations and very lesser activity in Parangipettai (Station-3). It would reveal the higher level of oil pollution in this Station-1 implicate stress to the inhabiting mussels, thus the mussels produced more of GSH for defense.

The observed lowest GSH activity during summer and monsoon in all the Stations indicates the climatic changes besides the xenobiotics (i.e., highest/lowest 
salinity and temperature stresses that deviate from the required optimum conditions for best performance) impart stress and thus modulates the activity. The same condition was already experienced in Uria aalge (Khan and Nag, 1993). It would further reveal the extreme climatic conditions may reduces the defense enzyme activity, thereby the loss of defense may leads death of the animals (Geracitano et al., 2000; Zakharov et al., 2002; Frei, 1999). Sies (1991) stated the GSH and other antioxidant enzyme activity depends on the survival ability relevance to the organism's biology. The instant depletion of GSH level would probably reveals enhanced risk of oxidative stress in digestive gland, gills and other parts of the body that induces the membrane and cellular damages.

Identical higher productions were obtained in rain bow trout fish exposed Phenobarbital, p, p-di chloroDiphenyl-Dichloro-Ethylene (DDE), or the prototypal oxidation-reduction cycling compound 2,3dimethoxynaphthoquinone (Petrivalsky et al., 1997). In the present study the long term exposure to elevate the xenobiotic concentrations inhibited the GSH reaction in $P$. vidis during summer season in the field (Figures), the same condition was already experienced in Uria aalge (Khan and Ryan, 1991). In another evaluation on the CYP 450 isoforms which are considered as biomarker enzymes showed higher activity during summer seasons and thus the present GSH depletion does not reflects oxidative stress during summer.

\section{ACKNOWLEDGEMENT}

The researchers wish to record their thanks to the Department of Ocean development, Govt. of India for financial support, DST-FIST and UGC-SAP for Instrumentation facilities.

\section{REFERENCES}

Arun, S. and P. Subramanian, 1998. Antioxidant enzymes in freshwater prawn Macrobrachium malcolmsonii during embryonic and larval development. Comp. Biochem. Physiol. Part B, Biochem. Mol. Biol., 121: 273-277. DOI: 10.1016/S0305-0491(98)10100-1

ASTM, 2003. ASTM C33 / C33M - 11a standard specification for concrete aggregates. ASTM International, West Conshohocken, PA. DOI: 10.1520/C0033_C0033M-11A

Bhat, S. and P.V. Desai, 1998. effect of thermal and salinity stress on Perna viridis heart (L.). Ind. J. Exp. Biol., 36: 916-919.
Bradford, M.M., 1976. A rapid and sensitive method for the quantitation of microgram quantities of protein utilizing the principle of protein-dye binding. Anal. Biochem. 72: 248-254. PMID: 942051

Carlberg, I. and E.B. Mannervik, 1975. Glutathione level in rat brain. J. Biol. Chem., 250: 4475-4480.

Chelikani, P., I. Fita and P.C. Loewen, 2004. Diversity of structures and properties among catalases. Cell. Mol. Life Sci., 61: 192-208. DOI: 10.1007/s00018003-3206-5

Correia, J.B., M.P. Caldas, N. Shohoji and A.C. Ferro, 1996. Dependence of internal oxidation rate of water atomized $\mathrm{Cu}-\mathrm{Al}$ alloy powders on oxygen partial pressure. J. Mater. Sci. Lett., 15: 465-468. DOI: 10.1007/BF00275403

Cossu, M., M.T. Perra, M. Piludu and M.S. Lantini, 2000. Subcellular localization of epidermal growth factor in human submandibular gland. Histochem. J., 32: 291-294. DOI: 10.1023/A:1004036929006

Frei, B., 1999. On the role of vitamin C and other antioxidants in atherogenesis and vascular dysfunction. Proc. Soc. Exp. Biol. Med., 222: 196204. PMID: 10601878

Geracitano, L., J.M. Monserrat and A. Bianchini, 2002. Physiological and antioxidant enzyme responses to acute and chronic exposure of Laeonereis acuta (Polychaeta, Nereididae) to copper. J. Exp. Mar. Biol. Ecol., 277: 145-156. DOI: 10.1016/S00220981(02)00306-4

Halliwell, B. and J.M.C. Gutteridge, 2007. Free Radicals in Biology and Medicine. 4th Edn., Oxford University Press, ISBN-10: 019856869X, pp: 851.

Irato, P., G. Santovito, E. Piccinni and V. Albergoni, 2001. Oxidative burst and metallothionein as a scavenger in macrophages. Immunol. Cell Biol., 79: 251-254. PMID: 11380678

Johnson, F. and C. Giulivi, 2005. Superoxide dismutases and their impact upon human health. Mol. Aspects Med., 26: 340-352. DOI: 10.1016/j.mam.2005.07.006

Khan, R.A. and K. Nag, 1993. Estimation of hemosiderosis in seabirds and fish exposed to petroleum. Bull. Environ. Contaminat. Toxicol., 50: 125-131. DOI: 10.1007/BF00196550

Khan, R.A. and P. Ryan, 991. Long term effects of crude oil on Common guillemots (Uria aalge) following rehabilitation. Bull. Environ. Contam. Toxicol., 46: 216-222. 
Khessiba, A., M. Romeo and P. Aissa, 2005. Effects of some environmental parameters on catalase activity measured in the mussel (Mytilus galloprovincialis) exposed to lindane. Environ. Poll., 133: 275-281. DOI: 10.1016/J.ENVPOL.2004.05.035

Livingstone, D.R., F. Lips, P.G. Martinez and R.K. Pipe, 1992. Antioxidant enzymes in the digestive gland of the common mussel Mytilus edulis. Mar. Biol., 112: 265-276. DOI: 10.1007/BF00702471

Lushchak, V.I. and T.V. Bagnyukova, 2006. Temperature increase results in oxidative stress in goldfish tissues. 1. Indices of oxidative stress. Compart. Biochem. Physiol. Part C: Toxicol. Pharmacol., 143: 30-35. $\quad$ DOI: 10.1016/J.CBPC.2005.11.017

Mannervik, B., 1987. The enzymes of glutathione metabolism: an overview. Biochem. Soc. Trans., 15: 717-718. PMID: 3315772

Meister, A. and M.E. Anderson, 1983. Glutathione. Ann. Rev. Biochem., 52: 711-760. DOI: 10.1146/annurev.bi.52.070183.003431

Nozik-Grayck, E., H.B. Suliman and C.A. Piantadosi, 2005. Extracellular superoxide dismutase. Int. 624 J. Biochem. Cell Biol., 37: 2466-2471. DOI: 10.1016/j.biocel.2005.06.012

Parihar, M.S., T. Javeri, T. Hemnani, A.K. Dubey and P. Prakash, 1997. Responses of superoxide dismutase, glutathione peroxidase and reduced glutathione antioxidant defenses in gills of the freshwater catfish (Heteropneustes fossilis) to shortterm elevated temperature. J. Therm. Biol., 22: 151156. DOI: $10.1016 / \mathrm{S} 0306-4565(97) 00006-5$

Petrivalsky, M., M. Machala, M. Nezveda, K., Piacka and V. Svobodova, 1997. Glutathione-dependent detoxifying enzymes in rainbow trout liver: Search for specific biochemical markers of chemical stress. Environ. Toxicol. Chem., 16: 1417-1421. DOI: $10.1002 /$ etc. 5620160714

Power, A. and D. Sheehan, 1995. Seasonal variations in the levels of antioxidant enzymes in Mytilus edulis. Biochem. Soc. Trans., 23: 354S-362S.

Rajagopal, S., G. van der Velde, J. Jansen, M. van der Gaag and G. Atsma et al., 2005. Thermal tolerance of the invasive oyster Crassostrea gigas: Feasibility of heat treatment as an antifouling option. Water Res., 39: 4335-4342. DOI: 10.1016/J.WATRES.2005.08.021
Santovito, G., E. Piccinni, A. Cassini, P. Irato and V. Albergoni, 2005. Antioxidant responses of the Mediterranean mussel, Mytilus galloprovincialis, to environmental variability of dissolved oxygen. Compart. Biochem. Physiol., C: Toxicol. Pharmacol., 140: 321-329. $\quad$ DOI: 10.1016/J.CCA.2005.02.015

Sies, H., 1991. Oxidative Stress: Oxidants and Antioxidants. 1st Edn., Academic Press, London, San Diego, ISBN-10: 0126427623, pp: 650.

Sturve, J., A. Berglund, L. Balk, K. Broeg and B. Bohmert et al., 2005. Effects of dredging in Göteborg harbor, Sweden, assessed by biomarkers in eelpout (Zoarces viviparus). Environ. Toxicol. Chem., 24: 1951-1961 PMID: 16152967

Subramanian, P., 1992. Organization of natural communities of juvenile Penaeid prawns. II. Community structure. Int. J. Ecol. Environ. Sci., 18: 237-244.

Valko, M., D. Leibfritz, J. Moncol, M.T. Cronin and M. Mazur et al., 2007. Free radicals and antioxidants in normal physiological functions and human disease. Int. J. Biochem. Cell Biol., 39: 44-84. DOI: 10.1016/j.biocel.2006.07.001

Wetzel, D.L. and E.S.V. Vleet, 2004. Accumulation and distribution of petroleum hydrocarbons found in mussels (Mytilus galloprovincialis) in the canals of Venice, Italy. Mar. Pollut. Bull., 48: 927-936. DOI: 10.1016/j.marpolbul.2003.11.020

Zakharov, S.D., T.I. Rokitskaya, V.L. Shapovalov, Y.N. Antonenko and W.A. Cramer, 2002. Tuning the membrane surface potential for efficient toxin import. Proc. Natl. Acad. Sci. USA., 99: 86548659. DOI: 10.1073/pnas. 122613099

Zamocky, M. and F. Koller, 1999. Understanding the structure and function of catalases: clues from molecular evolution and in vitro mutagenesis. Prog. Biophys. Mol. Biol., 72: 19-66. DOI: 10.1016/S0079-6107(98)00058-3

Zhang, J.F., H. Sen, T.L. Xu, X.R. Wang, W.M. Li and Y.F. Gu, 2003. Effects of long-term exposure of low-level diesel oil on the antioxidant defense system of fish. Bull. Environ. Contaminat. Toxicol., 71: 234-239. PMID: 14560372 